\title{
EXPANDING THE PARADIGM: BRINGING DESIGNERLY PERSPECTIVES INTO CREATIVITY SCHOLARSHIP
}

\author{
Danah HENRIKSEN* \\ Arizona State University, Mary Lou Fulton Teachers College, Division of Educational Leadership and \\ Innovation, Phoenix, Arizona, 85069 United States
}

Received 26 November 2018; accepted 17 February 2019

\begin{abstract}
Designerly ways of knowing have significant untapped potential to inform creativity research. In this article, I draw upon in-depth interviews with expert design scholars to examine this connection. Thematic analysis reveals how design offers potential lenses on creativity that are not often taken up in dominant psychological discourses around creativity. I situate this by framing the need for design-based knowledge within creativity literature. The findings reflect a view of creativity involving perception, intuition, and ability to re-see the world; creativity as an action-orientated phenomenon; and a focus on the ethics of creativity in an increasingly technology-empowered society. In exploring scholarly definitions of and views about creativity, there are insights on how design offers distinctive viewpoints for paradigms around creativity.
\end{abstract}

Keywords: creative epistemologies, creative paradigms, creative thinking, creativity, creativity research, design, designerly ways of knowing, ethics, intuition, perceiving.

\section{Introduction}

The arena of creativity research has frequently been framed by dominant psychological perspectives, which often explore it from individualistic, internalized perspectives around creative ability, skills or potential (Cropley 2003). In this article, I suggest that the common paradigms of creativity research and scholarship may be usefully informed by perspectives from the field of design. Designerly ways of knowing (DWK) have practicable and real-world framings, which are applicable to how creativity emerges in practice and in creative society (Dorst \& Cross, 2001).

I draw upon two in-depth interviews with expert design scholars, Richard Buchanan (Case Western Reserve University) and Paul Pangaro (College of Creative Studies), to examine how themes from the field of design can inform creativity research. These two indepth interviews are a smaller part of a larger-scale ongoing inquiry into the perspectives of expert creativity scholars (Henriksen, Mishra, Warr, \& The Deep-Play Research Group,

${ }^{\star}$ Corresponding author. E-mail: danah.henriksen@asu.edu 
2018a; Henriksen, Mishra, \& The Deep-Play Research Group, 2018b). Within this broader inquiry, these interviews were unique in that they captured the phenomenon of creativity from an expert design perspective (DP). Thematic analysis reveals how design offers lenses on creativity that are not frequently taken up in dominant psychological discourses (PDs) around creativity.

I situate this work by framing the need for design-based knowledge within creativity literature, followed by an overview of the research approach. The findings reflect several design-based perspectives on creativity, including: a view of creativity involving perception, intuition, and ability to re-see the world; creativity as an action-orientated phenomenon; and a focus on the ethics of creativity in an increasingly technology-empowered society. In exploring Pangaro's and Buchanan's definitions of and views about creativity, there are insights on how design offers distinctive viewpoints for creativity research.

\section{Literature situating creativity in design}

Creativity is a complex construct, and creative thinking has often been mythologized as an inherent ability - rather than a developed way of thinking and being in the world, as it is seen in design (Cross, 2001). Stretching back to antiquity and Plato's belief in the muse, there has been a mysterious element to creativity and a tendency in popular culture to assume that only gifted people have creative insights (Starko, 2014). While challenges and myths propagate around creativity, recent scholars have aimed to examine it more scientifically. Empirical research around creativity expanded from the latter half of the 20th century into the present - starting with J. P. Guilford's (1950) call to the American Psychological Association, to employ more space and attention to the study of creativity.

\subsection{Dominant creativity discourses in psychology research}

J. P. Guilford's (1950) call to action led to an uptick of research on creativity. Creativity scholarship has touched on (and built upon) research from neuroscience, economics, design, social justice, the arts, and more (Kaufman \& Sternberg, 2010). Yet for much of recent history, the most highly-touted academic research in this area has been situated in psychology, around the psychological aspects of individual creativity (Runco, 2014). Much of this dominant research discourse emerges from a cognitive perspective. Such perspectives are often focused on the self, and investigated through psychometric examination (Plucker \& Renzulli, 1999).

Creativity research and theories from psychology often aim to explain cognitive processes underlying creativity or cognitive styles in creative thinking (Cropley, 2003). Much creativity research through the late 20th century focused on psychometric approaches - or individualistic studies of creative potential within the mind, and development of a battery of tests measuring creative potential and performance (Runco \& Chand, 1995).

These dominant psychological discourses in creativity research have usefully advanced our understanding of individual creative potential (Runco, 2014). However, the focus on internal mental states, capacities and skills can also be limiting to and separate from the 
highly social, practical, and hands-on needs of creative practitioners (Horton et al., 2019). A psychometric test of individual creative capacity is as impractical to a designer or artist as it would be to a teacher supporting students in their creative development. There is not always a clear connection between much creativity research, and what people do in their daily work, lives and problem-solving (Glăveanu, 2014). It can be difficult to find direct applicability from such work into practice (Sternberg \& Lubart, 1999).

In addition, this focus on creativity as an object of "scientific" study has never fully dissolved the common belief in popular discourse that creativity is an inherent trait or only accessible to the creatively "gifted" (Cropley, 2016). This imbalance in locating academic research more heavily in one domain is thus problematic - for design, for creative education, or any fields or disciplines grounded in creative practice.

These dominant psychological discourses in creativity research are valuable to be sure. They have provided important insights and foundational understanding of creative human psychology. However, they also have limitations in terms of practice-based creativity or practical insights into creativity "in the wild", whether that be in classrooms, in applications of everyday creativity, or other creative work. At the same time, the discourses of design may have significant potential to inform practicable scholarly understandings of creativity. Some of these connections have been made within existing design research (DR), but there is clearly space within creativity scholarship to draw upon them.

Importantly, in this article I focus on design discourses to differentiate them from dominant creativity discourses which are frequently located in the field of psychology - thus I overview common findings or thinking from psychological research on creativity. When the field of education or even popular discourse points to knowledge, research or skills on the topic of creativity, what they frequently point to is drawn from common discourses in psychology (Runco, 2014). My object is to complicate this notion of psychology research as the default knowledge area on creativity, by highlighting DWK about creativity. That said, despite this heavy focus on psychology in common discourses, it is essential to note that much interesting, provocative, critical, and sometimes overlooked research on creativity has been located in a range of disciplinary fields, such as: sociology (Lowe, 2010), educational sciences (Gajda, Karwowski, \& Beghetto, 2017), economics (Greffe, 2016), management (Amabile, 1997), philosophy (Gaut, 2010), and various other cross-disciplinary areas. In placing a spotlight on a way of considering creativity from a disciplinary perspective such as design, I seek to broaden the conversation, and assert that a range of voices and disciplinary approaches are critical to highlight in order to explore a complex construct like creativity.

\subsection{Scholarly insights from design}

A common definition of creativity focuses on the processes of creating ideas, artifacts, processes, and solutions, that are novel and effective (J. M. Fox \& R. L. Fox, 2000). Design itself is the creative process of purposefully creating something that does not yet exist (Hoadley \& Cox, 2009). Design sits at the intersection of the arts and sciences, and is relevant to creative work in many human-centered disciplines (Cross, 2011). Designers' practices may be iterative or individualistic, but design creativity (DC) and choices are scaffolded and informed by common assumptions and ways of being in the world (Buchanan, 2001). 
Herbert A. Simon (the Nobel Laureate who founded design as a professional field) offered a definition of design applicable to creativity and human-centered problem-solving:

"Everyone designs who devises courses of action aimed at changing existing situations into preferred ones. The intellectual activity that produces material artifacts is no different fundamentally from the one that prescribes remedies for a sick patient or the one that devises a new sales plan for a company or a social welfare policy for a state" (1969, p. 130).

In this, design crosses disciplines around complex problems via creative solutions. $\mathrm{Bu}-$ chanan (2001) suggests that design involves using ability for creative problem-solving in ways that serve human needs. Design involves directing creativity towards goals, actions, and purpose around real world issues (Collins, Joseph, \& Bielaczyc, 2004). This positions design as a creative problem-solving and thinking approach for human-centered professions, such as doctors, engineers, educators or any creative practitioners (Henriksen, Richardson, \& Mehta, 2017).

Creativity and design practice are inextricably linked, such that David Wang and Ali O. Illhan suggest that "so central is the creative act to the design professions that we suggest that it is it, rather than a distinct body of knowledge, that resides at the cores of these professions" (2009, p. 6). Yet they note that, while the connection between design and creativity is sometimes addressed (Dorst \& Cross, 2001), it is remarkable that existing research tends not to account for adequately.

It is not that design scholarship ignores creativity - as Nigel Cross (2001), Simon (1969) and others do consider issues of creativity in design. Yet while creativity is central to design practice, this connection may not be as widely articulated in research as befits its centrality. Design insights on creativity can and should more strongly inform creativity scholarship which can benefit from a more practicable approach. Design is inherently tied to creativity in practical, accessible, and educative ways.

This article examines designerly insights on creativity in a small-scope individualized manner. I draw ideas from two in-depth design scholar interviews that are part of a broader and ongoing study of creativity (Henriksen et al., 2018a, 2018b). In these interviews, there are considerations for how design might infuse new perspectives into dominant creativity discourses.

\section{Research approach}

This work is derived from interviews collected as part of a larger research inquiry into the perspectives of scholars of creativity (across disciplines). This larger ongoing research inquiry has aimed to explore creativity across a range of discursive perspectives, in psychology, social justice, neuroscience, business, education, and notably, design. In this data, a similar pattern of related themes emerged from these two design expert interviews, which were distinct from the rest of the scholarly perspectives. They offered unique viewpoints not frequently foregrounded in common psychological creativity research. To explore this phenomenon, I separated out this small sample of in-depth qualitative interviews, to thematically investigate perspectives on creativity espoused by these design scholars. 
The data reported here are from a focused purposive qualitative sample, from my interviews conducted with two notable scholars of design - Buchanan and Pangaro, who provided illustrative cases of designerly perspective on creativity. Buchanan serves as professor of design and innovation in the Weatherhead School of Management at Case Western Reserve University, and chair professor of design theory, practice, and entrepreneurship in the College of Design and Innovation at Tongji University and is the Editor-in-Chief of Design Studies. Pangaro is associate professor and chair of the master of fine arts in interaction design program at the College for Creative Studies. These scholars were selected - having articulated scholarly perspectives around creativity - as part of an inquiry into how creativity scholars view the construct.

Through a semi-structured interview process (protocol in Appendix A), I explored their perspectives about creativity, in their definitions of and views about creativity in research and practice. As John W. Creswell (2007) recommends for in-depth interviews, each conversation lasted between 60-90 minutes. Each interview was conducted on video-conference via Zoom Video Communications, and then audio-transcribed by a professional transcription agent. In data analysis, I conducted an open coding to identify emergent ground-up themes (Quinn Patton, 2002) that could help to illustrate each interviewee's understanding of creativity. To then distill these codes, or "meaning units" (Moustakas, 1994), into a more contextual design-focused look at creativity, I compared between the two pieces to identify and interpret commonalities in themes and takeaways. I share thematic findings, which differ in both subtle and significant ways from common creativity discourses. I describe themes of intuition, perception, actionorientation and ethics - as grounded in DKW, relevant to broader understandings of creativity. In this data, I see to consider the research question: What are some takeaways or themes that creativity scholarship and research might draw upon from design?.

In sharing the qualitative findings from this study as follows, I directly quote Buchanan and Pangaro, drawn from research interviews with them. Per Creswell's (2007) suggestion for validation of qualitative findings, I use rich, thick description directly stating the interviewees own word, allowing the reader to validate and understand my interpretation and discussion of these ideas alongside the participants own comments.

\section{Limitations}

This is a small purposive sample which is not generalizable - although conventional research generalizability is not the intent of this work. I draw instead upon the qualitative principle of transferability, through which the reader may consider ideas within this work in terms of how they might be brought to bear across contexts (Lincoln \& Guba, 1985). The purposive nature of the sample also means that these ideas may not be representative of other design scholars/experts. However, expertise is an inimitable phenomenon colored by the lens of individual experiences, and thus is often unique to individuals.

\section{Findings}

These thematic insights, described in the next sections suggest: the value of perception or intuition for creativity and creativity as re-thinking or re-seeing; the social and action-orientated 
nature of creativity; and the ethics of creativity. These ideas grounded in design perspectives may provide a sense of the nature of creativity as viewed in design - perspectives that may contribute to the dominant creativity discourses and provide creative education with a unique lens for understanding. As noted in the research approach section above, the participants from this line of inquiry - Buchanan and Pangaro - are directly quoted based on their interviews for this study, towards a goal of rich, thick description (Creswell, 2007).

\title{
4.1. Creativity as perceiving, intuition, and re-seeing
}

In these interviews, a key emergent idea involved creativity as a way of perceiving the world and the role of intuition. Both interviewees spoke about this in terms of creativity as an ability to see and perceive. Despite slightly different semantics, there is conceptual overlap across Buchanan's view of creativity as a "perceiving the world, grounded in intuition", and Pangaro's view of creativity as capacity for "seeing and re-seeing" the world. I describe how some of these ideas emerged in our interviews, first in a subtheme denoting Buchanan's framing around perception and intuition, and in a subtheme focused on Pangaro's closely-related perspective about openness to re-seeing or perceiving the world.

Creativity as perception and intuition. Buchanan noted how modern psychological views on creativity could benefit from classical philosophical grounding in human-centered thinking. In particular, he draws upon ideas from classical philosophy to suggest creativity as a way of viewing and framing the world.

Buchanan described how in ancient Greek or Roman philosophy, the study of what are called topics or topoi, are a source of creativity, noting:

\begin{abstract}
"The opposition is between a topic and a category. Categories help us to fix the meanings of things. If I say "chair", you think of a categorical term "chair", and you can look up the definition. But if I take "chair" and say, "Can I break that category? Can I change that categorical meaning? Can I make it something other than we understand? Something that's not familiar now but that could become?". That's where creativity and invention play. A topic is the key tool, intellectually, for melting down the categories around us. That's what designers do. They melt the categories where we think we know what is, and show us what could be" (see Henriksen et al., 2018b).
\end{abstract}

This view of creativity is inherently grounded in design, central to the way we perceive the world in terms of relationships between ideas, objects or categories. Topics or topoi are basic categories of relationships among ideas, which give designers an outline or heuristic for envisioning things to say or think about a subject. "Topics of invention" literally translates to "places to find things". In design work, this becomes a way of using language to perceive and re-envision what we think we know. This perceiving and rethinking - inextricably linked to design, is a defining point of creativity.

Within our human minds - what we know, and think we know, constitutes our associations about the external world. Cognitive psychology tells us how these associations are structured into categories, helping us understand certain things in relation to other things (Halpern, 1998). Such categorization is a function of memory - allowing humans to hold and manipulate more information by grouping and categorizing like and unlike things (Squire, 2004). So categories have a functional psychological purpose. But the flip side is that they can produce tensions 
and constraints to creativity, because bases for comparison or differentiation can also become barriers to making novel associations or to breaking down the familiar. When we believe that we simply know what we know, we limit our perceptions of possibilities.

Buchanan suggests that topics or topoi are fundamental to how designers rethink knowledge, question assumptions, or make the familiar unfamiliar. While the idea of "making the familiar strange" has occasionally been addressed in creativity literature, it may be more fundamental than we know. Such perception is fundamental to creativity and design. Buchanan described how we must be able to use this kind of perceiving, and also go beyond it:

"I teach my design students something else. I teach them about invention, about how to use topics. All of this is concerned with how we perceive, and what we perceive. Creativity is nothing more, and nothing less, than a perception of what is not familiar, what we don't know, what we don't have in front of us. Really to perceive is the key, so I teach my students how to perceive in new ways" (see Henriksen et al., 2018b).

Related to this are insights and intuitions - as intuitions include the ability to see or make the connection between different categories, or think in a more holistic manner. Buchanan offered the example of Henry Ford's insights, noting how his inspiration for the invention of the assembly line originated from seeing pig carcasses in a Chicago meat plant moving down the line as the carvers cut off slices. This example suggests an ability to make deep and diverse connections between categories - since a view of a meat plant would not, at surface-level, suggest the future design of the automotive industry. If Ford had remained in the categorization of "meat plant" when perceiving this system, he would not have seen a solution by "melting the categories" for applicability to the automotive industry.

Then there is the role of intuition, because Ford also chose to double the salary of his worker - which seemed entirely contradictory and counterintuitive at the time. But this decision constituted a unique intuition about the system, because by doubling the salaries he created an entire new audience of consumers for his product.

This notion of intuition is fundamental to creativity in design. Across much of the research literature on creativity, and even most educational literature, there is limited acknowledgement of the role of intuition. It is difficult to even find ways to draw it into the research discourses, yet it is essential to how people operate creatively in the world.

There is research within cognitive psychology dealing with expert intuition (Lieberman, 2000). But this is often discussed as a by-product of accumulated knowledge stored and reconfigured or accessed as needed. The focus on memory in psychology is limited to preexisting knowledge. Thus, it is different from intuition in a design-centered view of creativity, which can break the norms of known or conventional knowledge (e.g. in the Ford example, he worked from an intuition guided by a sense of the whole system, since no prior economic knowledge or modeling was available to guide that decision). Creativity does not rely on regularity or expectations of the known world. As Buchanan comments:

"Intuition is a significant matter in creativity. In reading Spinoza, in his Ethics, he says that the sequence is imagination and reason, but beyond imagination and reason, intuition gives us the greatest knowledge. Now what could he possibly mean by that, except the ability to perceive some deeper connection, some deeper system that goes beyond our arguments and our rational structures? To grasp a wholeness. I think this is what designers do. They grasp the wholeness of a product" (see Henriksen et al., 2018b). 
This view of design, and creativity, as an act of perception or grasping of wholeness, explains how creators make or discover things, like products, artifacts, ideas, and more. Grasping the wholeness of a system becomes a way of learning to see - an idea espoused by another expert design interviewee, Pangaro.

$D C$ involves re-thinking or re-seeing. Pangaro's background, training and design interests are grounded in cybernetics, which informs his perspective on creativity. He points out that his cybernetic perspective should not be confused with cyborgs, or robots, or artificial intelligence. Instead it is, as Pangaro says,

"the cybernetics of the original field, which came out of a transdisciplinary conversation with anthropologists, linguists, philosophers, psychiatrists, engineers and mathematicians as a way to imagine systems that had a purpose" (see Henriksen et al., 2018a).

Most common scholarly definitions of creativity highlight novelty and effectiveness as core elements. But while this gives us a baseline view of creativity, it tells us little about how it happens. A defining factor of these design interviews is that they attended to how creativity emerges. Pangaro's definition, similar to Buchanan's "perceiving", views creativity as a way or an act of "re-seeing" from a fresh perspective. Pangaro noted that:

"There are different ways to think about creativity. The way I think about creativity, and from a cybernetic viewpoint, is that creativity is a matter of seeing something anew - seeing in a new way. It's seeing something in a way that you hadn't seen it before, and that new way is effective; it's something that helps you get to where you want to be" (see Henriksen et al., 2018a).

Pangaro's definition of creativity also states that it should help you "get to where you want to be”. This recalls Simon's classic definition of design:

"Everyone designs who devises courses of action aimed at changing existing situations into preferred ones. The intellectual activity that produces material artifacts is no different fundamentally from the one that prescribes remedies for a sick patient or the one that devises a new sales plan for a company or a social welfare policy for a state" (1969, p. 130).

This focus on moving from "existing" to "preferred" or to "where you want to be" is a defining element of design thinking (DTH) that could serve common understandings of creativity. And these elements of seeing and re-seeing, or perceiving and intuition, become central to what designers do, and what creativity is.

Pangaro described human perceptions as a personal language for viewing, interpreting and transforming the world around us. In Pangaro's view, this language involves distinctions, values, and relationships, toward complex perceiving:

"I could describe a visual language in what I see. I see a person. I see a background. I see a vent in the upper right of the room. Some of these things are relevant, and some are not, to what our purpose may be. But I could also say I see shapes, or I see black against white and foreground and background. These are different frames or languages in the sense of distinctions, values, and relationships. We always have these frames or languages when we look at anything. As we look at a problem in front of us, we have these filters" (see Henriksen et al., 2018a). 
Creativity necessitates seeing beyond our filters to allow for novel and effective (i.e. creative) angles. The ways in which he describes a shift in perspective have similarities to $\mathrm{Bu}$ chanan's view of topics as a way to melt categories. Buchanan notes:

"We have a paradigm which suggests a way to look at the world. For me creativity is breaking out of that paradigm - seeing new distinctions, new relations, and possibly developing their values. And this is very consistent with a lot of ideas in design and design methods, and also, in the distinction between problem-solving and problem-framing" (see Henriksen et al., 2018b).

This issue of problem-framing spans creativity, design, and education, though design has always had a strong claim in this arena, both in illuminating but also necessarily complicating it. Pangaro commented:

"We tend to think of creativity as problem-solving. But if I tell you what the problem is, I've already narrowed how I am seeing it, and therefore, I narrow what possibly may come from it. So, in teaching and thinking about design, ask 'how do I look at the world and what is the language with which I look at the world?' Therefore, within that language, what is possible?" (see Henriksen et al., 2018a).

Thus, taking care with finding or framing problems is essential to creating solutions. Pangaro's reflection that, "if I tell you what the problem is, I've already narrowed how I am seeing it" is echoed in Horst Rittel's and Melvin M. Webber's (1973) seminal idea of wicked problems - a type of problem formulation situated in design by Buchanan (2001). In one core principle of wickedity, "The choice of explanation determines the nature of the problem's resolution" (Rittel \& Webber, 1973, p. 166) - meaning that appropriate problem definition is critical, illuminating this focus on learning to perceive, to see and re-see.

Alongside problem-framing, Pangaro reflected on processes used by designers to engage in creative work. For instance, he suggested that the process of "observe, reflect, make" can be applied in iterations to the same problem, exploring and narrowing towards a creative solution. The mind must also be prepared for creativity, and Pangaro suggested "immersion in ideas, a willingness to try different things, allowing yourself to be distracted, meditating, using intuition are serendipitous ways in which things happen" (see Henriksen et al., 2018a).

Techniques that help us to slow down and rethink have been suggested as ways of creatively cross-pollinating ideas (Claxton, 2006). For instance, mind-wandering and meditation are seemingly different arenas that have both been linked to creative thinking (Baird et al., 2012; Sarath 2006). Mind-wandering requires undirected attention and loose exploration, and meditation requires a practice of heighted awareness and attention (the breath, a mantra, etc.) on a specific focus. But these practices might contribute in different ways to the sometimes divergent and sometimes convergent elements of creative processes - as preparation for the actional practice of creating.

\subsubsection{The action-orientated nature of design creativity}

A core aspect of DC is its action-orientated nature. Namely, both interviewees spoke about the fact that in design, creativity is framed through action, embodiment, physicality or materiality in action with the world around us. Much creativity literature tends to, overtly or indirectly, view creativity in mainly cognitive terms, as a function or offshoot of human minds. 
Design research tends to include more thinking on the tangible world, and often locates knowledge within the body, material interactions, or emerging in action. In other words, there is a focus toward thinking through doing, or doing as thinking. Pangaro described how a bias-toward-action frames DC, and differentiates it from scientific knowing, saying:

\footnotetext{
"Science has its goal to accumulate knowledge. Cybernetics [or design] has as its goal to understand how to act effectively, so it's about action. It's not just about knowing. And in that sense, so is creativity. It's about an action toward getting where you want to be, other than where you are now. You want to make progress" (see Henriksen et al., 2018a).
}

In this design-centered creativity there is pragmatism and direction toward "action" and "progress", which designers have emphasized as an inherently purposeful act (Schön, 1983). This purpose-driven factor differentiates DC from pure artistic creativity, which yields more individual expression. Design must create something toward a need or purpose for others. Pangaro called back to Simon's (1969) previously-stated definition of design, which is actionorientated toward affecting change for people and situations.

Pangaro asserted that this definition gives a clear mission of action to design, locating it in the material world as much as the mind. Donald Schön suggested that design may be understood as dialogue with the world - a dialogue between the designer and his or her stakeholders, materials, environment, and the evolving design itself (1983). This resonates deeply with Pangaro's views of design as a dialogic and material action, as he notes that, "without conversation, we wouldn't have society and we wouldn't have effective collaboration and effective action" (see Henriksen et al., 2018a).

Buchanan also reflected at multiple points upon the ways that creativity emerges in the action of doing in design. At one point he noted, within the context of the difference between design and systems analysis,

"systems analysis is important for understanding environments and surroundings in which we work, but it's only for that interpretation. Design is a separate problem entirely $<\ldots>$. Designers make things. If you want to have action, go to a designer" (see Henriksen et al., 2018b).

Buchanan defines creativity as a complex phenomenon, also orientated to action. In describing creativity, he commented that, "I see a cluster of terms, I see 'invention', 'discovery', 'innovation', and 'intuition'. Those four terms are, to me, the dimensions of what we call 'creativity"' (see Henriksen et al., 2018b). In teaching these constructs to his own students, he noted the difference between invention and discovery, such that:

"Discovery is when you take an invention and apply it to experience. That's when you discover facts about the world. And when you take that discovery and try to do something with it, you push that invention through discovery into action" (see Henriksen et al., 2018b).

This idea of creative action as thinking by doing is important. Buchanan is a proponent of educational philosopher John Dewey's $(1916,1934)$ notions of creative education, framed around the principle of learning by creating or thinking in doing. This applies to his own teaching, as Buchanan noted:

"I call design thinking 'creative inquiry'. It is a form of creative action [emphasis added], and I work with students to help mold their experiences of perceiving new things, 
and show them some principles that guide coming up with new ideas $<\ldots$. . This means asking and answering good questions about every situation $\langle\ldots\rangle$. The ability to ask questions of the environment, to interrogate the environment, and to find the answers, shows this great perceptive capability" (see Henriksen et al., 2018b).

The Deweyan notion of creative learning by experience, inquiry and engagement with the arts and humanities runs deep in Buchanan's views, as he stated, "Design education pioneered the notion of teaching by projects, and Dewey's concern for doing and making as part of education is so much at the center of that" (see Henriksen et al., 2018b). Thus, the artistic experiential and inquiry-based nature of design work connects it to higher order thinking by way of action - which suggests that we can educate people for creativity.

\subsection{The ethics of creativity in design}

An interesting facet of these design interviews was that they both raised the importance of ethics (although "ethics in creativity" was not in any question that they were asked). Within the larger set of creativity-focused interviews, ethics rarely emerged as an explicit, central part of the conversation. In its role in design, it may have arisen because designers must (or should) consider the ethics of their creations. Given the pace of technological acceleration in our society, concerns about ethics may be even more front-and-center to designers.

Thus, it arose in the context of discussing implications for the future of creative society. For instance, Pangaro noted that despite his own appreciation for technological design, there are crucial ethical questions here for creativity, saying:

"I love to hack - I'm fascinated by the newest iPhone or devices, but I also want to hear the discourse that is questioning what is changing and what is not changing, and what we want to conserve as people. As a society - what are our values and what do we want? The technology is so overwhelming, amazing and fascinating that you sit in a restaurant and nearly everybody has devices in front of them, even if they're with other people" (see Henriksen et al., 2018a).

This brought Pangaro to the value of dialogue, and its role in establishing our human values and ethics. He noted that when technology impedes or diminishes those values, it becomes concerning or problematic. There are new areas of potential and possibility that support creativity and conversation. But, those possibilities can only be realized if our society, and creators of technology, ask difficult questions about how we interact with new tools, as he said:

"What are your beliefs? How do you operate in the world? What do you want? What kind of a world do you want? Whether that's a world at large, or a world between the two of you - every pairing or small group of people has their own private world in which they interact" (see Henriksen et al., 2018a).

In a similar vein, Buchanan also raised the importance of asking foundational ethical questions in situations of DC. He described addressing this issue in design education:

"I had students write a paper on the question of whether it's possible to teach ethics to artificial intelligence? The papers that came back were fascinating. We had a range of views - on the spectrum from could to couldn't. What was most interesting was the discussion in class. We focused on what is it that makes ethics significant? Is ethics 
a set of rules? Rules you can code? If so, then no problem. But is that ethics? And what are the judgments we make? What is compassion? How do we make a judgment about what should be? It is wise to not follow a rule? That's a human judgment. I was delighted with how they discussed, understood and addressed the ethical issues" ((see Henriksen et al., 2018b).

Pangaro also noted that creativity should be driven by the values and distinctions that we want to honor as a society. In terms of creativity and what it means to be human, we must continually revisit value judgments with awareness of the effects of our creations. There are implications for how we train and educate the next generation of creative practitioners. He noted:

"It's about using technology in service of the human values, and going toward the technology from a purpose, rather than starting from the technology and saying, "Hey, I can connect people", "Hey, I can do advertisements", or "Hey, I can take a selfie and make it last five seconds and disappear in seven seconds", or whatever. The reason why coders should study philosophy and ethics and many other things is about creativity and fostering new insight - but also to be conscious of their values and to know that every line of code has some value implicit" (see Henriksen et al., 2018a).

Buchanan also suggested that considering the implications of everything that we design is essential in a human sense, and that while design itself is morally neutral, the designer is not. For example, he noted:

"The Holocaust was one of the most tragic, prominent products of design in the 20th century. It was designed thoroughly, but with a horrifying ethical foundation. And the fault lies in the people. Albert Spear and his surrounding henchmen. It was not a matter of design. Design is a neutral tool. But designers need to know when and how to use design and when not to use it" (see Henriksen et al., 2018b).

He suggested that embedding this ethical aspect of creativity into the education of creative practitioners is crucial, saying:

"I spend a portion of every course I teach on ethics. There's a great book by Caroline Whitbeck on ethics in engineering research. She explores the grammar of ethics to know the terminology, and the proposition that design itself is ethical action. We usually think of ethics as the judgment of past actions. But for Whitbeck it's the design of future actions that becomes ethical in a deep way" (see Henriksen et al., 2018b).

Buchanan did not express his designerly views about tools or technologies as an optimist, pessimist, advocate or naysayer. He noted that technology can be a site for creativity. Yet he did express concern that we as a society must become more aware, knowledgeable, and humane:

"We tend to reduce technology to the hardware and the software, and that's a problem. I don't think it gets in the way of creativity. It's certainly another place for creativity $\langle\ldots\rangle$. But we have to remember that design is significant because of its concern for human beings. Without principled concern for the dignity of human beings, it's worthless" (see Henriksen et al., 2018b).

This recalls Buchanan's grounding in the humanities and its role in his views on creativity. The human and ethical side of creativity emerged strongly for both of these design scholars. A clear thread of beliefs about creativity in design foregrounds human beings as central, and a sense of ethics as critical to the fabric of good, human-centered creativity. 


\section{Discussion}

These themes reflect what these design experts/scholars described as core in their beliefs about creativity. The interviews aimed to understand their guiding perspectives on creativity in the context of design expertise - and these themes of creativity as perceiving, intuition and/or re-seeing the world; creativity as an action-oriented phenomenon; and a focus on ethicality, all emerged here. These interviews rarely called upon the dominant cognitive perspectives on creativity which are often found at the foreground of the most widely-known creativity research. Design has unique perspectives which might be further explored in future inquiries into creativity or opened up by drawing on more design framings in other avenues of creativity research.

\subsection{Distinctions between design and dominant creativity discourses}

Creativity as perceiving, intuition, and re-seeing. The idea that creativity is an act of perceiving, requiring intuition and an ability to re-see or re-think, was important to these scholars. Creativity becomes a way of seeing that "re-sees" what is, to break out of existing paradigms and "see anew - creating new distinctions, new relations, and possibly developing their values", as Pangaro put it. Buchanan also emphasized this re-seeing, and further noted that it is guided by a developed intuition, which allows designers to be creative, by intuiting the problem as a whole and having intuition or instincts about new possibilities.

Creativity scholarship has often focused on the novel and effective products of creativity, or on individual psychological tendencies, processes or cognitions that lead to them; and thus has frequently considered creativity in terms of traits, abilities, cognitive skills, or personality characteristics (Prabhu, Sutton, \& Sauser, 2008). These approaches give us a vital part of the story - but only part. This focus may constrain notions like intuition or perception. Jason Gallate and Shannan Keen (2011) describe scholarship on creative intuition, but often in ways that focus on theory or neuroscientific concepts. Similarly, Jessica Fleck and John Kounios (2009) describe some work devoted to intuition and creativity, but this is limited somewhat in amount and scope to psychophysiological or philosophical work, rather than grounded in real-world creative practice. So while intuition is not entirely ignored in creativity studies, the work on this topic is few-and-far-between in the scope of creativity research. Moreover, philosophical or neuroscientific work on intuition - while important in its own right - is of less practical use for creative education and practice.

In psychology, work on expert intuition is often separate from creativity discourse or is framed as a psychological function of memory organization and structure (Squire, 2004). Buchanan frankly stated that a design view of creativity should depart from this, noting that, "creativity is not entirely bound by memory" (see Henriksen et al., 2018b). In some dominant discourses - such as those of Buchanan's once-colleague Simon, or in Daniel Kahneman's work (1973) - Buchanan noted that common perspectives assume that:

\footnotetext{
"Creativity is a matter of deep exploration of the brain's ability to hold past experiences $\langle\ldots\rangle$ a reconfiguration of what already exists in memory. I think that is a mistake $\langle\ldots\rangle$ [because] it doesn't exhaust the story. I see intuition as a very significant matter in creativity. [Creativity] $\langle\ldots\rangle$ is the ability to perceive some deeper connection, some
} 
deeper system that goes beyond our arguments and our rational structures. To grasp a wholeness. And I think this is what designers do" (see Henriksen et al., 2018b).

Memory is a critical concept - but the exclusive focus on it has repercussions in disciplines. In education, which often draws upon psychology of learning, there is not a common language, outside of falling back upon memory, to attend to the role of developing intuition in students' creative thinking and learning. Buchanan is explicit about how his view of creativity does not assume that designerly creative intuitions are inherent or mystical. They can be learned or developed:

"Can you teach creativity? My belief is yes, you can. Certainly. To 95 percent of the population you can teach it. I get tired of the idea that creativity is something esoteric and elite. It's not. When you help people to perceive new possibilities for their own lives, how they lead their lives, that's a major development" (see Henriksen et al., 2018b).

He suggests creativity is teachable, by teaching people how to perceive (e.g. the use of topics or topoi to melt the categories), to ask questions and make connections. Such perspectives might benefit the research on creativity in practical areas of creative work, or in education overall.

Creativity as action-orientated. Another core theme pointed to creativity as an action-orientated phenomenon. This suggests that creativity is not solely in the mind or the individual but emerges in the action of doing. Thus, it becomes an interaction with the material world. Within design literature, this recalls Schön's (1983) notion of design as a dialogue - emerging in a kind of dialectic action between the designer and the world; creativity is produced within a dialogue between the designer and his or her stakeholders, materials, environment, and the evolving creative work itself.

A bias toward action, or thinking through doing aligns with practical design knowledge and creative work. There is of course still a critical role for individual mental workings of the mind, but this also occurs in tandem with action in the material world. For instance, the Stanford d.chool has suggested that design requires moving ideas and explorations out of the head and into the physical world, where one can create with the ideas and build toward something tangible.

In psychology, there has been research on embodied cognition or the idea of thinking via material interactions. But in creativity, this is a relatively small sub-branch of research. Recent design scholars have taken up the idea that DTH practices connect with research on embodied cognition - linking the practices of sketching and prototyping with theory that explains how understanding emerges relevant to actionable experience (Lindgaard \& Wesselius, 2017).

Some social perspectives (SPs) on learning (Vygotsky, 1978) emphasize cognition in terms of social moves or interactions with the world. While important in education, this has only recently translated into creativity research. Recent creativity work has drawn on SPs (Sawyer, 2012), but there may be space for a stronger increased role for design perspectives to reflect practical creativity within academic research. By increasing focus on creating via the action of doing, rather than mainly on internal, mental cognitions, we might explore how creativity emerges in situ. In education, this could permit a more accessible view of creativity, as emerging through doing, rather than something locked within the mind or inherent to individual psychology. 
The role of ethics in creativity. Finally, the role of ethics in creativity is critical to design. "Ethics" emerged as a term across both interviews - a divergence from other creativity scholar interviewees. That is not to say that scholars of creativity do not consider ethics. For instance, in his definition of creativity, Arthur J. Cropley moves beyond most definitions of creativity as novelty and effectiveness, to add ethicality to the mix for a three-part definition, noting that "creative is not generally a word that describes cruel or destructive behavior, crimes, warmongering, etc." (2003, p. 6).

That said, many definitions of creativity do not draw directly on ethics, and much common creativity research does not address ethicality. Again, this is not for a lack of interest or belief in ethicality among most researchers. It may be more likely due to the focus on psychology of creativity rather than on contextual or societal factors surrounding the interactions between users and creative products or ideas - a strong focus in design (Kimbell, 2011).

Perhaps because design deals directly with the products of creativity, there is an unavoidable awareness of the ethicality and implications of creative products for the people they serve. Some scholarship dealing with ethics emerges in philosophy, which is rarely located in real-world outcomes. The intensely human-centered creative focus of design demands an attention to such implications in concrete, real-world terms of tangible effects.

Both interviewees reflected on the need for increasing awareness of ethics among creators, given the accelerating pace of technology in our world. The rate of constant change means that humans must think reflexively and nimbly, guided by deeply ethical perspectives, to ensure that what we create serves societal values. The ethicality of creativity may be an avenue of consideration for broader creativity research - given greater voice by the DWK.

\section{Conclusions}

These themes suggest the potential of design to inform existing and future paradigms of creativity scholarship. I have noted how many dominant paradigms of creativity have been drawn from the field of psychology - work that, although relevant and important - can be limited by its disciplinary lenses. Design perspectives are as embedded in contextual, realworld settings as they are in the individual minds of designers, and may provide alternate approaches to creative epistemologies. Thus these themes of: perception, intuition and rethinking or re-seeing; the action-orientated nature of creativity; and the ethics of creativity, demonstrate a few ways that design can offer a lens to inform other creativity paradigms.

A design-centric approach to creativity may offer a path for orienting epistemologies of creativity toward practice - to extend future thinking in creativity research. It is important to note that creativity and design processes are rich and complex areas of practice or expertise. I do not seek to reduce them to merely these themes or suggest that researchers can easily extract the kinds of deep professional knowledge that creative practitioners operate with into a set of common findings.

These themes are merely a few of many possibilities that might emerge in future or largerscope studies - for example, concepts such as empathy or cross-disciplinarity, among others, are defining and salient design principles. The point is not solely in the findings noted here, but in the potential of DWK to inform traditional scholarly discourses of creativity. Findings 
drawn from design may have variabilities of context, and would expand beyond themes distilled in this article. However, by drawing from design, the arena of creativity research may broaden and deepen its reach into more practicable, DWK. In bringing about a more complete and richer perspective of scholarship and epistemologies of creativity, we may also bring research closer to practice in creative society.

\section{Acknowledgements}

The author acknowledges the intellectual contributions of interviewees Buchanan (Case Western Reserve University) and Pangaro (College of Creative Studies), with gratitude for sharing their time and expertise in this line of work. Also, the Deep-Play Research Group is acknowledged as significant to the ideas presented here in terms of framing the larger inquiry that this work draws upon.

\section{References}

Amabile, T. M. (1997). Motivating creativity in organizations: On doing what you love and loving what you do. California Management Review, 40(1), 39-58. https://doi.org/10.2307/41165921

Baird, B., Smallwood, J., Mrazek, M. D., Kam, J. W. Y., Franklin, M. S., \& Schooler, J. W. (2012). Inspired by distraction: Mind wandering facilitates creative incubation. Psychological Science, 23(10), 1117 1122. https://doi.org/10.1177/0956797612446024

Buchanan, B. G. (2001). Creativity at the Metalevel: AAAI-2000 Presidential Address. American Association for Artificial Intelligence, 22(3), 13-28.

Claxton, G. (2006). Thinking at the edge: Developing soft creativity. Cambridge Journal of Education, 36(3), 351-362. https://doi.org/10.1080/03057640600865876

Collins, A., Joseph, D., \& Bielaczyc, K. (2004). Design research: Theoretical and methodological issues. The Journal of the Learning Sciences, 13(1), 15-42. https://doi.org/10.1207/s15327809jls1301_2

Creswell, J. W. (2007). Qualitative inquiry \& research design: Choosing among five approaches. Thousand Oaks, CA: Sage Publications, Inc.

Cropley, A. J. (2003). Creativity in education \& learning: A guide for teachers and educators. London and New York: Routledge.

Cropley, A. (2016). The myths of heaven-sent creativity: Toward a perhaps less democratic but more down-to-earth understanding. Creativity Research Journal, 28(3), 238-246. https://doi.org/10.1080/10400419.2016.1195614

Cross, N. (2011). Design thinking: Understanding how designers think and work. London: Berg. https://doi.org/10.5040/9781474293884

Cross, N. (2001). Designerly ways of knowing: Design discipline versus design science. Design Issues, 17(3), 49-55. https://doi.org/10.1162/074793601750357196

Dewey, J. (1934). Art as experience. New York: Penguin Putnam.

Dewey, J. (1916). Democracy and education: An introduction to the philosophy of education. New York: Macmillan Company.

Dorst, K., \& Cross, N. (2001). Creativity in the design process: Co-Evolution of problem-solution. Design Studies, 22(5), 425-437. https://doi.org/10.1016/S0142-694X(01)00009-6

Fleck, J. I., \& Kounios, J. (2009). Intuition, creativity, and unconscious aspects of problem solving. In W. P. Banks (Ed.-in-Chief). Encyclopedia of consciousness, Vol. 1 (pp. 431-446). Cambridge, MA: 
Elsevier Inc. https://doi.org/10.1016/B978-012373873-8.00042-6

Fox, J. M., \& Fox, R. L. (2000). Exploring the nature of creativity. Dobuque, IA: Kendall/Hunt Publishers Company.

Gajda, A., Karwowski, M., \& Beghetto, R. A. (2017). Creativity and academic achievement: A metaanalysis. Journal of Educational Psychology, 109(2), 269-299. https://doi.org/10.1037/edu0000133

Gallate, J., \& Keen, S. (2011). Intuition. In M. A. Runco \& S. R. Pritzker (Eds.-in-Chief). Encyclopedia of Creativity (pp. 683-688). San Diego, CA: Academic Press.

https://doi.org/10.1016/B978-0-12-375038-9.00278-8

Gaut, B. (2010). The philosophy of creativity. Philosophy Compass, 5(12), 1034-1046. https://doi.org/10.1111/j.1747-9991.2010.00351.x

Glăveanu, V. P. (2014). The psychology of creativity: A critical reading. Creativity: Theories - Research Applications, 1(1), 10-32. https://doi.org/10.15290/ctra.2014.01.01.02

Greffe, X. (2016). From culture to creativity and the creative economy: A new agenda for cultural economics. City, Culture and Society, 7(2), 71-74. https://doi.org/10.1016/j.ccs.2015.12.008

Guilford, J. P. (1950). Creativity. American Psychologist, 5(9), 444-454. https://doi.org/10.1037/h0063487

Halpern, D. F. (1998). Teaching critical thinking for transfer across domains: disposition, skills, structure training, and metacognitive monitoring. American Psychologist, 53(4), 449-455. https://doi.org/10.1037/0003-066X.53.4.449

Henriksen, D., Mishra, P., Warr, M., \& The Deep-Play Research Group. (2018a). A cybernetic perspective on design and creativity: A conversation with Dr. Paul Pangaro. TechTrends, 62(1), 6-10. https://doi.org/10.1007/s11528-017-0232-y

Henriksen, D., Mishra, P., \& The Deep-Play Research Group. (2018b). Creativity as invention, discovery, innovation and intuition: An interview with Dr. Richard Buchanan. TechTrends, 62(3), 215-220. https://doi.org/10.1007/s11528-018-0279-4

Henriksen, D., Richardson, C., \& Mehta, R. (2017). Design thinking: A creative approach to educational problems of practice. Thinking Skills and Creativity, 26, 140-153.

https://doi.org/10.1016/j.tsc.2017.10.001

Hoadley, Ch., \& Cox, Ch. (2009). What is design knowledge and how do we teach it? In Ch. DiGiano, Sh. Goldman, \& M. Chorost (Eds.), Educating learning technology designers: Guiding and inspiring creators of innovative educational tools (pp. 19-35). New York: Routledge.

Horton, A., Henriksen, D., Mishra, P., Seals, Ch., Shack, K., \& Marcotte, C. (2019). Creativity and the urban teacher: A STEM-related professional development program. In C. A. Mullen (Ed.), Creativity under duress in education? Resistive theories, practices, and actions. Series: Creativity Theory and Action in Education, Vol. 3 (pp. 289-312). Cham: Springer Nature Switzerland AG. https://doi.org/10.1007/978-3-319-90272-2_16

Kahneman, D. (1973). Attention and effort. Series: Prentice-Hall Series in Experimental Psychology. Englewood Cliffs, NJ: Prentice-Hall, Inc.

Kaufman, J. C., \& Sternberg, R. J. (Eds.). (2010). The Cambridge handbook of creativity. Cambridge: Cambridge University Press. https://doi.org/10.1017/CBO9780511763205

Kimbell, L. (2011). Rethinking design thinking: Part I. Design and Culture, 3(3), 285-306. https://doi.org/10.2752/175470811X13071166525216

Lieberman, M. D. (2000). Intuition: A social cognitive neuroscience approach. Psychological Bulletin, 126(1), 109-137. https://doi.org/10.1037/0033-2909.126.1.109

Lincoln, Y. S., \& Guba, E. G. (1985). Naturalistic inquiry. Newbury Park: Sage Publications, Inc.

Lindgaard, K., \& Wesselius, H. (2017). Once more, with feeling: Design thinking and embodied cognition. She Ji: The Journal of Design, Economics, and Innovation, 3(2), 83-92.

https://doi.org/10.1016/j.sheji.2017.05.004 
Lowe, Ph. (2010). Enacting rural sociology: Or what are the creativity claims of the engaged sciences? Sociologia Ruralis: Journal of the European Society for Rural Sociology, 50(4), 311-330. https://doi.org/10.1111/j.1467-9523.2010.00522.x

Moustakas, C. (1994). Phenomenological research methods. Thousand Oaks, CA: Sage Publications, Inc. https://doi.org/10.4135/9781412995658

Plucker, J. A., \& Renzulli, J. S. (1999). Psychometric approaches to the study of human creativity. In R. J. Sternberg (Ed.), Handbook of creativity (pp. 35-61). Cambridge: Cambridge University Press.

Prabhu, V., Sutton, Ch., \& Sauser, W. (2008). Creativity and certain personality traits: Understanding the mediating effect of intrinsic motivation. Creativity Research Journal, 20(1), 53-66. https://doi.org/10.1080/10400410701841955

Quinn Patton, M. (2002). Qualitative research \& evaluation methods. Thousand Oaks, CA: Sage Publications, Inc.

Rittel, H. W. J., \& Webber, M. M. (1973). Dilemmas in a general theory of planning. Policy Sciences, 4(2), 155-169. https://doi.org/10.1007/BF01405730

Runco, M. A. (2014). Creativity. Theories and themes: research, development, and practice. Amsterdam: Academic Press.

Runco, M. A., \& Chand, I. (1995). Cognition and creativity. Educational Psychology Review, 7(3), 243267. https://doi.org/10.1007/BF02213373

Sarath, E. (2006). Meditation, creativity, and consciousness: Charting future terrain within higher education. Teachers College Record, 108(9), 1816-1841. https://doi.org/10.1111/j.1467-9620.2006.00763.x

Sawyer, R. K. (2012). Explaining creativity: The science of human innovation. Oxford, New York: Oxford University Press, Inc.

Schön, D. A. (1983). The reflective practitioner: How professionals think in action. New York: Basic Books, Inc.

Simon, H. A. (1969). The sciences of the artificial. Cambridge, MA: The MIT Press.

Squire, L. R. (2004). Memory systems of the brain: A brief history and current perspective. Neurobiology of Learning and Memory, 82(3), 171-177. https://doi.org/10.1016/j.nlm.2004.06.005

Starko, A. J. (2014). Creativity in the classroom: Schools of curious delight. New York, NY: Routledge.

Sternberg, R. J., \& Lubart, T. I. (1999). The concept of creativity: Prospects and paradigms. In R. J. Sternberg (Ed.), Handbook of creativity (pp. 3-15). Cambridge: Cambridge University Press.

Vygotsky, L. S. (1978). Mind in society: The development of higher psychological processes. Cambridge, MA: President and Fellows of Harvard College.

Wang, D., \& İlhan, A. O. (2009). Holding creativity together: A sociological theory of the design professions. Design Issues, 25(1), 5-21. https://doi.org/10.1162/desi.2009.25.1.5

\section{Appendix A}

\section{Semi-structured protocol}

Creativity interview questions

1. Please share a little about yourself and your background. Looking back, what initiated your interest in these areas?

2. How do you define creativity? What has driven your views on creativity and how has your view on it been similar or different from other scholars? 
3. In what ways do you see issues of creativity overlapping with your professional expertise, either or both in scholarship or practice?

4. What do you think are some of the main challenges faced by scholars who study creativity - in general, and more specifically in your own professional field?

5. Are there any insights you have gained from research, scholarship, or your own experiences and practice that might inform educators or policymakers?

6. Can you suggest any ways of communicating such ideas to people in education?

7. Given your perspective, do you think creativity can be developed/nurtured/taught? If so, how?

8. How do you think technology has changed the way we think about creativity and its development (positively, negatively, ... both, neither)? Are there any current trends in technology that you see as being important?

9. Are there other questions I should have asked, or crucial points around creativity that we missed talking about? If so, what are those questions or issues, and how might you address them?

\title{
PARADIGMOS IŠPLĖTIMAS: DIZAINO PERSPEKTYVŲ ITRAUKIMAS İ KŪRYBINt UGDYMĄ
}

\author{
Danah Henriksen
}

\section{Santrauka}

Dizaineriško pažinimo būdai turi reikšmingų nepanaudotų galimybių praturtinti kūrybiškumo tyrinejimus. Siekdama išnagrinèti šį ryši, straipsnyje remiuosi išsamiais interviu su dizaino srityje dirbančiais mokslininkais ekspertais. Teminè analizè atskleidžia, kaip dizainas kūrybiškumui suteikia galimybių, atveriančių jo perspektyvas, kurios nėra pasitelkiamos vyraujančiuose psichologijos diskursuose, susijusiuose su kūrybiškumu. Tam skiriu dèmesio, kūrybiškumui skirtoje literatūroje sukurdama dizainu grindžiamų žinių poreikį. Išvados atspindi kūrybiškumo vaizdą, apimantị suvokima, intuiciją ir gebejjima naujaip pažvelgti ị pasaulį; kūrybiškumą kaip $\mathfrak{i}$ veiksmą nukreiptą reiškinị ir $\mathfrak{i}$ kürybiškumo etikq visuomenejje, kurioje vis didesnių galių iggyja technologijos. Tyrinejjant mokslinius kūrybiškumo apibrèžimus ir nusistatymus jo atžvilgiu, kyla įžvalgų apie tai, kaip dizainas formuoja išskirtinius požiūrius ị kūrybiškumo paradigmas.

Reikšminiai žodžiai: kūrybinè epistemologija, kūrybinès paradigmos, kūrybinis mąstymas, kūrybiškumas, kūrybiškumo tyrinèjimai, dizainas, dizaineriški pažinimo būdai, etika, intuicija, suvokimas. 